\title{
PENGETAHUAN HUKUM TENT ANG HUKUM ACARA PERDATA
}

Halida Zia, Mario Agusta, Desy Afriyanti. AZ.

\author{
Dosen dan mahasiswa pada Fakultas Hukum Universitas Muara Bungo \\ Jl. Diponegoro No. 27 Kelurahan Cadika, Kecamatan Rimbo Tengah, \\ Kabupaten Bungo Telp/Fax (0747) 323310 Kode Pos 37214 \\ E-mail :halidazia621@yahoo.co.id umb101016@gmail.com desy13@yahoo.co.id
}

\section{RINGKASAN}

Hukum acara perdata adalah serangkaian kaidah, prosedur, dan peraturan hukum yang mengatur pelaksanaan hukum perdata pada tata hukum positif yang berlaku di Indonesia. Dalam penegakan hukum perdata materiil perlu adanya hukum formil yang mengatur tentang bagaimana hukum materil terlaksana sebagaimana yang diatur dalam peraturan perundangundangan yang berlaku di indonesia guna tidak terjadinya main hakim sendiri (Eigenrechting. Berbeda dengan hukum acara pidana yang telah memilki sumber hukum tersendiri yang diatur dalam Kitab Undang-Undang Hukum Acara Pidana (KUHAP) sedangkan sumber hukum acara perdata masih bermber dari beberapa undang-undang sektoral seperti Undnag-Undang Nomor 1 Tahun 1974 Tentang Perkawinan yang mengatur tentang teknis pelaksanaan serta beberapa undang-undang lainnya.

Keywords: Hukum Acara Perdata, Sumber Hukum Acara perdata

\section{PENDAHULUAN}

\section{Latar Belakang}

Hukum Acara Perdata Adalah Peraturan Hukum yang mengatur bagaimana caranya menjamin ditaatinya hukum perdata materil dengan perantara hakim. Dalam kata lain Hukum Acara Perdata ialah Pengaturan Hukum yang mengatur bagaimana caranya mengajukan Hak, Memeriksa serta memutuskannya pelaksanaan dari pada putusan dengan perantara hakim. Tuntutan dalam hal ini adalah tindakan yang bertujuan untuk memperoleh perlindungan hokum yang diberikan pengadilan untuk mencegah Eigenrichting (Tindakan main hakim sendiri). Tindakan main hakim sendiri merupakan tindakan untuk melaksanakan hak menurut kehendaknya sendiri yang bersifat sewenang-wenang tanpa persetujuan dari pihak yang berkepentingan sehingga menimbulkan kerugian.

\begin{abstract}
Kata "Acara" disini berarti Proses Penyelesaian perkara lewat hakim (Pengadilan), Proses penyelesaian perkara lewat hakim ini bertujuan untuk memulihkan hak seseorang yang merasa dirugikan/terganggu, mengembailikan suasana seperti dalam keadaan semula bahwa setiap orang harus mematuhi peraturan hokum perdata, sehingga peraturan hokum perdata berjalan sebagaimana mestinya. Secara Teologis Hukum Acara Perdata adalah peraturan hokum yang berfungsi untuk mempertahankan berlakunya hokum perdata dengan tujuan meminta keadilan lewat hakim, hokum acara perdata dirumuskan sebagai peraturan hokum yang mengatur proses penyelesaian perkara perdata lewat hakim (Pengadilan) sejak dimajukannya gugatan samapai dengan pelaksanaan putusan hakim.
\end{abstract}


Dalam Peraturan Hukum Acra Perdata ini mengatur tentang :

1. bagaimana cara seseorang mengajukan perkara kepada hakim (Pengadilan).

2. Bagaimana cara pihak yang terseran mempertahankan diri.

3. Bagaimana hakim bertindak terhadap pihak-pihak yang berpekara yang dapat diselesaikan secara adil.

4. Bagaimana cara melaksanakan putusan hakim sebagaimana hak dan kewajiban seseorang yang telah diatur dalam hukum perdata dapat berjalan sebagaimana mestinya.

Dengan adanya Hukum Acara Perdata, seseorang dapat memuihkan kembali

haknya yang telah dirugikan/terganggu lewat hakim yang akan berusaha menghindarkan diri dari tindakan main hakim sendiri, lewat hakim seseorang mendapatkan kepastian hokum akan haknya yang harus dihormati oleh setiap orang seperti : Hak sebagai ahli waris, hak sebagai pemilik barang dan lain sebagainya.

Hukum Acara Perdata dapat disebut juga dengan Hukum Perdata Formil yang berarti seluruh kaidah hokum yang menentukan dan mengatur cara bagaimana melaksanakan hak-hak dan kewajiban-kewajiban perdata sebagaimana diatur dalam hUkum perdata materil.

Hukum Acara Perdata Bertujuan :

1. Mengetahui bagaimana cara yang harus dilalui seseorang agara perkara yang dihadapinya dapat diperiksa oleh pengadilan.

2. Mengetahui bagaimana cara Pemeriksaan suatu perkara dilakukan

3. Mengetahui bagaimana cara Pengadilan Menjatuhkan Putusan atas perkara yang diperiksa.

4. Mengetahui bagaimana cara agar putusan Pengadilan itu dapat dijalankan sehingga maksud dari orang yang mengajukan perkaranya kepengadila dapat tercapai.

Sumber-Sumber Hukum Acara Perdata

1.Burgerlijke Wetbook (BW).

1. Rechtsreglement Voor de Buitengewesten (RGB).

2. Reglement of de Burgelijke Rechtsvordering (RV).

3. Undang-Undang No 4 Tahun 2004 (Tentang Kekuasaan Kehakiman).

4. Undang-Undang No 8b Tahun $1989 \quad$ (Tentang Kepailitan).

5. Undang-Undang No 1 Tahun 1974 (Tentang Perkawinan).

6. Undang-Undang No 14 Tahun 1985 (Tentang Mahkamah Agung).

7. Undang-Undang No 20 Tahun 1947 (Tentang Peradilan Ulang).

8. Yurisprudensi (Keputusan Hakim Terdahulu).

9. Doktrin (Keputusan para ahli Hukum).

10. Adat/Kebiasaan.

11. Instruksi dan Surat Edaran Mahkamah Agung.

\section{PERMASALAHAN}

Bagaimana ruang lingkup hukum acara perdata di Indonesia? 


\section{PEMBAHASAN}

Asas-Asas Hukum Acara Perdata

1. Hakim Bersifat Menunggu

Hakim Bersifat Menunggu berarti hakim tidak boleh aktif mencari-cari perkara dimasyarakat, tetapi jika ada suatu perkara yang diajukan kepada hakim maka hakim tidak boleh menolak untuk memeriksa dan mengadilinya dengan alasan apapun sesuai dengan Undang-Undang Nomor 4 Tahun 2004 tentang Kekuasaan Kehakiman.

\section{Hakim Pasif}

Hakim Pasif artinya yaitu Ruang lingkup/luas pokok sengketa yang diajukan kepada hakim untuk diperiksa pada asasnya ditentukan oleh pihakpihak yang berpekara dan pengadilan dilarang untuk menolak memeriksa, mengadili dan memutuskan suatu perkara yang diajukan kepadanya dengan dalih bahwa hokum tidak ada atau kurang jelas. Hakim membantu para pencari keadilan dan berusaha mengatasi segala hambatan dan rintangan agar tercapainya keadilan.

Sifat hakim hanya mengkaji dan memutuskan perkara.

3. Sidang Perkara Terbuka Untuk Umum

Sidang Perkara Terbuka Untuk Umum yang artinya setiap orang berhak untuk menghadiri dan mendengarkan pemeriksaan perkara persidangan, namun ada beberapa persidangan yang bersifat tertutup, seperti persidangan kasus tentang asusila guna untuk menjaga nama baik bagi para korbannya.

Belah Pihak

$$
\text { 4. Mendengarkan Kedua }
$$

Mendengarkan Kedua Belah

Pihak artinya haruslah hakim bersifat netral dan memperlakukan sama antara pelapor dan terlapor keterangan kedua belah pihak untuk didengarkan penjelasannya secara bersama-sama.

5. Putusan Harus disertai AlasanAlasan

Putusan Harus disertai AlasanAlasan artinya segala putusan hakim harus memiliki dasar yang kuat untuk memutuskan suatu perkara dan hakimbertanggung jawab atas putusannya tersebut.

6. Beracara dikenakan Biaya

Beracara yang dikenakan biaya disini maksudnya biaya perkara yang meliputi biaya kepaniteraan dan biaya untuk panggilan, pemberitahuan para pihak serta biaya materai.

7. Tidak Ada Keharusan Mewakilkan

Tidak Ada Keharusan Mewakilkan Maksudnya disini ialah tidak mewajibkan orang untuk mewakilkan kepada orang lain apabila hendak berperkara dimuka pengadilan, baik sebagai penggugat maupun tergugat, sehingga pemeriksaan dipersidangan dapat terjadi secara langsung terhadap pihak yang berkepentingan.

8. Kekuasaan Kehakiman

Kekuasaan Kehakiman artinya Hakim memiliki peran yang utama dalam memutuskan perkara dan sifat putusan hakim ini mutlak untuk kedua belah pihak.

\section{Kekuasaan Kehakiman}

Kekuasaan Kehakiman adalah Kekuasaan Negara yang Merdeka untuk menyelenggarakan peradila guna menegakkan Hukum dan keadilan berdasarkan Pancasila dan UndangUndang Dasar Negara Republik Indonesia Tahun 1945, demi terselenggaranya Negara Hukum Republik Indonesia yang diatur dalam Undang-Undang Nomor 48 Tahun 2009 tentang Kekuasaan Kehakiman. UndangUndang Dasar Negara Republik 
Indonesia Tahun 1945 menegaskan bahwa Indonesia adalah Negara hokum. Sejalan dengan ketentuan tersebut maka salah satu prinsip penting Negara hokum adalah adanya jaminan penyelenggaraan kekuasaan kehakiman yang merdeka, bebas dari pengaruh kekuasaan lainnya untuk menyelenggarakan peradilan guna menegakkan hokum dan keadilan.

\section{Undang-Undang Dasar Negara}

Republik Indonesia Tahun 1945 menegaskan bahwa kekuasaan kehakiman merupakan kekuasaan yang merdeka untuk menyelenggarakan peradilan guna menegakkan hokum dan keadilan. Kekuasaan kehakiman dilaksanakan oleh sebuah Mahkamah Agung dan Badan Peradilan yang berada dibawahnya dalam lingkungan peradilan umum, lingkungan peradilan agama, lingkungan peradilan militer, lingkungan peradilan tata usaha Negara dan oleh sebuah Mahkamah Konstitusi.

a. Mahkamah Agung

Mahkamah Agung

berwenang mengadili pada tingkat kasasi, menguji peraturan perundangundangan dibawah undang-undang terhadap undang-undang dan mempunyai wewenang lainnnya yang diberikan oleh undang-undang.

\section{b. Mahkamah Konstitusi}

Mahkamah Konstitusi berwenang untuk menguji UndangUndang terhadap Undang-Undang Dasar Negara Republik Indonesia Tahun 1945 dan memutus sengketa kewenangan lembaga Negara yang kewenangannya diberikan oleh UndangUndang Dasar Negara Republik Indonesia Tahun 1945.

\section{c. Komisi Yudisial}

Komisi Yudisial berwenang mengusulkan pengangkatan hakim agung dan mempunyai wewenang lain dalam rangka menjaga dan menegakkan kehormatan, keluhuran martabat, serta perilaku hakim.

Peradilan

Perbedaan Pengadilan dan

\section{Pengadilan}

Pengadilan adalah Badan atau Instansi Resmi yang melaksanakan system peradilan berupa memeriksa, mengadili dan memutus perkara

\section{Peradilan}

Peradilan adaln suatu proses yang dijalankan dipengadilan yang berhubungan dengan tugas memeriksa, memutus dan mengadili perkara. Adapun jenis-jenis peradilannya:

1. Pengadilan Negeri

Fungsi Pengadilan

Negeri ialah untuk memeriksa, memutus dan menyelesaikan perkara pidana dan perdata bagi rakyat pencari keadilan pada umumnya.

2. Pengadilan Agama

Fungsi Pengadilan Agama ialah menyelenggarakan penegakan hukum dan keadilan dalam perkara terntu antara orang-orang yang beragama islam dibidang perkawinan, wasiat, waris, hibah, wakaf, zakat, infaq, shadaqah dan ekonomi syari'ah.

\section{Pengadilan Militer}

Fungsi Pengadilan Militer ialah bertugas untuk memeriksa dan memutuskan pada perkara pidana dan sengketa Tata Usaha Militer.

4. Pengadilan Tata Usaha Negara (TUN)

Fungsi Pengadilan TUN ialah untuk memerikasa, memutus, dan menyelesaikan yang termasuk dalam ranah sengketa Tata Usaha Negara yang mana adalah administrasi Negara.

5. Pengadilan Khusus

Pengadilan Khusu adalah pengadilan yang mempunyai wewenang untuk memeriksa, mengadili dan memutuskan perkara tertentu yang hanya dapat 
dibentuk dalam salah satu lingkungan badan peradilan yang berada dibawah Mahkamah Agung yang diatur dalam Undang-Undang.

Contohnya : Pengadilan TIPIKOR, Pengadilan anak, Pengadilan niaga yang diatur oleh undang-undang tersendiri.

Dalam memeriksa dan memutuskan perkara di bagi menjadi dua jenis :

1. Pemeriksaan ditingkat Pertama (Origial Jurisdiction)

Pada pemeriksaan ditingkat pertama ini berkedudukan di kota madya atau di ibu kota kabupaten, yang tugas dan wewenang nya ialah memeriksa, memutus dan menyelesaikan perkara pidana atau perdata ditingkat pertama.

2. Pemeriksaan ditingkat Banding (Appellate Jurisdiction)

Pemeriksaan ditingkat banding merupakan pemeriksaan ulang atau pemeriksaan dalam tingkat kedua, sebagai pengadilan tingkat banding kedudukannya di ibu kota provinsi, yang tugas dan wewenangnya adalah mengadili perkara pidana dan perdata ditingkat banding.

\subsection{Mahkamah Agung}

Mahkamah Agung merupakan puncak peradilan tertinggi yang berada didalam keempat lembaga perasila yang terkandung didalam Pasal 20 UndangUndang Kekuasaan Kehakiman. Tugas Mahkamah agung yakni :

1. mengadili pada tingkat kasasi terhadap putusan yang diberikan pada tingkat terakhir oleh pengadilan disemua lingkungan peradilan yang berada dibawah Mahkamah Agung, Kecuali Undang-Undnag menentukan yang lain.

2. Menguji Peraturan PerundangUndnag dibawah Undang-Undnag terhadap Undang-Undang

3. Kewenangan lainnya yang diberikan Undang-Undang.
Kewenangan Mahkamah agung terdapat didalam Pasal 28 ayat 1 UndangUndang Mahkamah Agung Memeriksa dan memutus diantaranya :

1. Permohonan Kasasi.

2. Sengketa tentang kewenangan mengadili.

3. Permohonan peninjauan kembali putusan pengadilan yang telah memperoleh kekuatan hukum tetap.

4. Menguji Peraturan perundangundangan dibawah undang-undang terhadap undang-undang.

Kewenangan Mahkamah Konstitusi didalam Pasal 24C Ayat 1 UndangUndang Dasar 1945 ialah mengadili pada tingkat pertama dan terakhir yang putusannnya bersifat final untuk :

1. Menguji Undang-Undang terhadap UUD 1945.

2. Memutus sengketa kewenangan lembaga Negara yang kewenangannya diberikan oleh UUD 1945.

3. Memutus pembubaran partai politik.

4. Memutus perselisishan hasil pemilu.

\section{KESIMPULAN}

Hukum acara perdata berjuan untuk menegakkan hukum perdata materiil guna terselenggaranya supremasi hukum yang berintegritas. Adapun perbedaan antara hukum perdata dan hukum acara perdata adalah mengenai substansi dan penegakan atau mekanismenya.

\section{DAFTAR PUSTAKA}

\section{BUKU}

Harahap Yahya, 2015, Hukum Acara Perdata, Sinar Grafika, Jakarta. 
Mertokusumo Sudikno, 2006, Hukum Acara Perdata Indonesia, Liberty, Jogjakarta.

Saija Ronal, 2015, Hukum Acara Perdata Indonesia, Deepublish.

Sarwono, 2015, Hukum Acara Perdata Dalam Teori dan Praktek, Sinar Grafika, Jakarta.

\section{JURNAL}

Anita Afriana, Penetapan Sita Eksekusi Oleh Pengadilan Tanpa Didasari Diktum
Putusan Akhir Yang Mengabulkan Sita Jaminan (Analisis Terhadap Perkara Nomor

332/PDT.G/2016/PN.JKT.SEL. Jurnal Adhaper, Vol. 6, No. 1 (2020).

Sherli Ayuna Putri, Upaya Hukum Banding Terhadap Putusan Verstek Yang Diajukan Oleh

Pihak Tergugat Dikaitkan Dengan Asas Kepastian Hukum dan Tinjaun HIR/RBG, Jurnal Adhaper, Vol. 6, No. 1 (2020) 